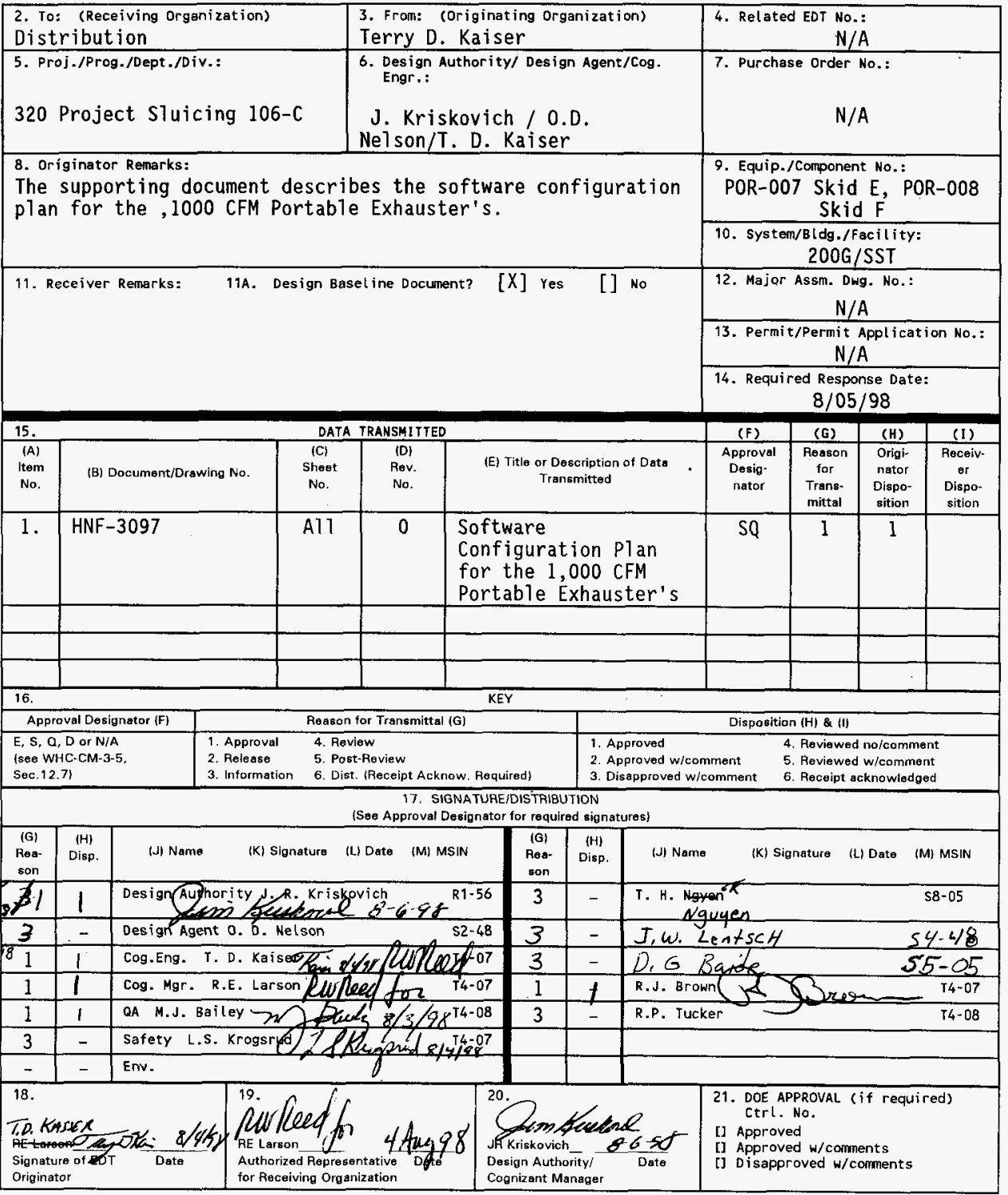




\section{SOFTWARE CONFIGURATION PLAN FOR THE 1,000 CFM PORTABLE EXHAUSTER'S SMALL LOGIC CONTROL SYSTEM}

T. D. Kaiser

Lockheed Martin Hanford Corporation, P.0. Box 1500, T4-07, Richland, WA 99352

U.S. Department of Energy Contract DE-AC06-96RL13200

$\begin{array}{lll}\text { EDT/ECN: } & \text { EDT-620743 } & \text { UC: UC-2000 } \\ \text { Org Code: } & 74800 & \text { Charge Code: N1W6B } \\ \text { B\&R Code: } & \text { EW3120071 } & \text { Total Pages: } \lambda_{8} 8 \mathrm{c} / 3-98\end{array}$

Key Words: Software Configuration Control Plan, , Allen-Bradley, 1,000 CFM Portable exhauster program, Saltwell exhauster, SLC 500 .

Abstract: This document describes the formal documentation for maintaining the control system associated with the 1,000 CFM Portable exhauster's. The objective of the software configuration control plan is to provide assurances that the portable exhauster's control system will be operable for the duration of 241-C-106 and 241-AY-102 operations (project 320 ). The design was based upon the criteria documented in the portable exhauster functional design criteria (HNF-SD-WM-DB-035) and procurement specification (HNF-S-0490) for the exhauster interlock systems.

TRADEMARK DISCLAIMER. Reference herein to any specific commercial product, process, or service by trade name, trademark, manufacturer, or otherwise, does not necessarily constitute or imply its endorsement, recommendation, or favoring by the United States Government or any agency thereof or its contractors or subcontractors.

Printed in the United States of America. To obtain copies of this document, contact: Document Control Services, P.O. Box 950, Mailstop H6-08, Richland WA 99352, Phone (509) 372-2420; Fax (509) 376-4989.
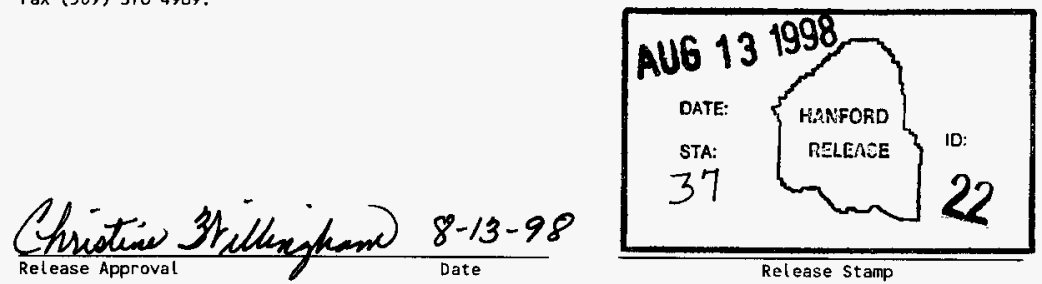

Approved for Public Release 


\title{
SOFTWARE CONFIGURATION PLAN FOR THE 1,000 CFM PORTABLE EXHAUSTER'S CONTROL SYSTEM
}

\author{
Prepared by \\ Terry D. Kaiser \\ Single Shell Tank Engineering
}

April 29, 1998

Lockheed Martin Hanford Corporation

Richland, Washington 


\section{CONTENTS}

1.0 SOFTWARE CONFIGURATION CONTROL . . . . . . . . . . . . . . - 1 1.1 INTRODUCTION .......................... 1 -

1.2 SCOPE ...................... . . 1 . .

1.3 PROJECT SCOPE ......................... 1 . .

2.0 SOFTWARE QUALITY ASSURANCE REQUIREMENTS . . . . . . . . . . . . -2 -

2.1 PERSONNEL AUTHORIZED TO MAKE CHANGES ............ - 2 -

2.2 METHODS, PROCEDURES, INSTRUCTIONS AND STATUS . . . . . . 2 -

2.2.1 METHODS ..................... -2 . 2 .

2.2.2 PROCEDURES .................. . . $3-$

2.2.3 INSTRUCTIONS ............... . . 3 -

2.2.4 SOFTWARE STATUS ............... -3 . 3 .

2.3 OPERATION AND MAINTENANCE ................ . . 3 2.3.1 SOFTWARE CUSTODIAN ............... . . 4 2.3.2 SOFTWARE MAINTENANCE .. . . . . . . . . . . . . -4 2.3.3 SOFTWARE PROTECTION . . . . . . . . . . . . . $4-$ 2.3.4 DATA PROTECTION ................ . . 5 2.3.5 PROTECTION FROM CATASTROPHE .......... . 5 - 5

2.3.6 PROCUREMENT ITEMS ............... -5 -

2.4 DESIGN LIFE AND DECOMMISSIONING . . . . . . . . . . . 5 - 
HNF-3097, Rev. 0

1.0 SOFTWARE CONFIGURATION CONTROL

1.1 INTRODUCTION

The objective of the software configuration control plan is to provide assurances that the 1,000 CFM portable exhauster's control system will be operable for the lifetime of the stabilization project. To remain operable the control system shall be maintained by engineering (Single Shell Tank Engineering [SSTE]) personnel. The computer operating system provides control of the portable exhauster equipment and is used for normal plant operations. Safety shutdowns of the exhauster system's are performed remotely (with operator interface console) and manually (The 320 project will not be utilizing the operator interface console).

1.2 SCOPE

This $\mathrm{plan}$ covers the following topics: Personnel authorized to make changes to the ladder logic, the methods, procedures and instructions used to control the identification of, access to, changes to, and the status of computer software. Configuration control documentation shall identify the changes to the ladder logic and work packages (e.g., test plans) shall be used to verify and validate the changes.

The ladder logic used on the control exhauster system is Flour Daniel North West FDNW) developed. All validation and verification shall be accomplished by FDNW and supplied to Lockheed Martin Hanford Company (LMHC) SSTE, as requested, prior to the use of updated software. A11 changes to the software sha11 be done by SSTE or any other contractors designated by the LMHC SSTE.

\subsection{PROJECT SCOPE}

The design was based upon the criteria documented in the portable exhauster functional design criteria (HNF-SD-WM-DB-035) and procurement specification (HNF-5-0490) for the exhauster interlock systems. After programming the ladder logic, the FDNW assisted in installing and testing the equipment on-site. If required, a contract will be issued to the supplier for any of the following: vendor software, Ladder logic, or hardware assistance.

The operator control console software WonderWare Corporation (Wonderware [not being utilized by the 320 project]), Rockwell Software Incorporated (A.I.) interfaces with the Allen-Bradley SLC-500 small programmable logic controllers, and Allen Bradley (Message Builder configuration software). 
HNF-3097, Rev, 0

The A.I. software, Rockwell software and Allen Bradley software was purchased by LMHC. The engineering Point-of-Contact (POC) is the engineering (SSTE) HVAC Cog. Engineer, currently Terry D. Kaiser (otherwise known as the Software Custodian).

\subsection{SOFTWARE QUALITY ASSURANCE REQUIREMENTS}

\subsection{PERSONNEL AUTHORIZED TO MAKE CHANGES}

The only personnel allowed to make changes to the ladder logic are members of the engineering organization (SSTE). Two members of engineering (SSTE) that have been trained on software are Terry $D$. Kaiser and Toan Nguyen. These two individuals shall have the "System Administrator" access to the ladder logic and vendor supplied software. The password to be used to enter the ladder logic level of the program shall be held by these two individuals and a copy of all passwords shall be supplied to the SSTE Manager. Two engineers and the engineering (SSTE) manager shall be authorized to access the ladder logic.

Two engineers shall be capable of working with the control station. The engineering personnel shall be capable of forcing functions (inputs and outputs) from the control console (lap top computer), as required for testing. A1l forcing functions and any identified control system problems shall be documented in the Portable exhauster control log. The logbook in located in the operations shift office. All process variables approved for different application are located on $\mathrm{H}-14-102608$ and will require an ECN to reconfigure the exhauster process variables and control interlocks.

\subsection{METHODS, PROCEDURES, INSTRUCTIONS AND STATUS}

This document defines the control methodology to be used to maintain the ladder logic configuration.

\subsubsection{METHODS}

The Tadder logic is identified in engineering supporting document HNF-2934, Portable 1,000 CFM exhauster Skids POR-007, Skid E and POR-008, Skid $F$. The ladder logic shall be maintained by using the current supporting document change control process [Engineering Change Notices [ECN]). All permanent changes to ladder logic shall go through the formal change control (ECN) process. The level of the change to the ladder logic shall determine the level of independent overview organization (QA and Safety) reviews required. These changes do not include process variable's which are done on an ECN and work package. The changes when incorporated into the computer ladder logic shall be recorded in the Portable exhauster control system logbook. 
HNF-3097, Rev. 0

\subsubsection{PROCEDURES}

Operations and Engineering can start-up the work stations, when required. Engineering may need operations/maintenance personnel to perform certain tasks, when evaluating on the exhauster equipment. operations/Maintenance personnel control the normal output functions of the system.

\subsubsection{INSTRUCTIONS}

The operations personnel are trained to operate the control system by either engineering personnel or experienced operators. All normal exhauster activities shall be performed via operating procedure(s).

Any testing of the 1,000 CFM portable exhauster system's components shall be performed and controlled by maintenance procedures, functional test procedures, functional checks, or via work package instructions. The type of test (a graded approach to testing) is dependent upon the level of change implemented. The cognizant engineer is responsible for authorizing testing documentation (test plans, etc).

\section{2 .4 SOFTWARE STATUS}

The operation of the exhauster's shall be monitored by the engineering personnel. The software existing on each of the computers shall be reviewed by the engineering personnel, to assure the control system functions properly. Any changes to the computer systems (e.g., addition of memory) sha11 be documented in the portable exhauster control system logbook.

If the current version of the A.I. operating system software is being replaced with a later version, the engineering personnel shall perform functional checks to ensure the new version works properly (is compatible with the current computer system hardware and software). All testing by engineering personnel shall be documented in the Portable exhauster control system logbook.

\subsection{OPERATION AND MAINTENANCE}

The control system computers shall be operated by the (SST) operations personnel and maintained by the (SSTE) engineering personne?.

\subsubsection{SOFTWARE CUSTODIAN}

The individual assigned responsibility for identification, configuration control, distribution, problem notification, and maintenance of the computer programs is the engineering (SSTE) HVAC Cognizant Engineer. As previously stated the Software Custodian is the HVAC Cognizant engineer (Terry D. Kaiser). Toan Nguyen is assigned as the cognizant engineer backup of the portable exhauster control system. 
HNF-3097, Rev. 0

\subsubsection{SOFTWARE MAINTENANCE}

If necessary the Wonderware software can be maintained by procuring a yearly maintenance contract with the vendor for this software.

The maintenance contract(s) provides updates to the software and operational support, if the software fails or indicates problems. The funding for the maintenance contract(s) shall be provided by operations (SST) and the Software Custodian, or SSTE Manager shall be identified to the software vendor as the POC.

Master electronic copies of the software (the vendor supplied software and the developed ladder logic) shall be installed in the SLC CPU and on at least one other engineering (SSTE) workstation. The engineering (SSTE) workstation(s) shall be physically located in another building. The Wonderware developed software works on the basis of a key (software) disc system. Hence, only the machine with the software key installed on it can operate the software. Key discs are available from the Software Custodian, if an immediate need for a second key arises keys may need to be purchase from the vendor.

Each version or revision of the A.I. software is uniquely identified. The associated documentation that defines the changes in the software by each revision shall be obtained and entered into the vendor information (VI) file.

The software master discs shall be maintained by the Software Custodian.

The Software Custodian is responsible to identify (Portable exhauster control system logbook.) that the software and the backup software (on the engineering [SSTE] workstation[s]) are the same version. The Software Custodian is responsible to install all software on all platforms.

\subsubsection{SOFTWARE PROTECTION}

The A.I. software is protected from vandalization by using password protection. As previously stated, the access to the computers and software requires knowledge of the system and is password protected.

\subsubsection{DATA PROTECTION}

The data files associated with the A.I. software are located in the SLC computers and on at least one engineering (SSTE) workstation.

The data files shall be maintained by the Software Custodian. The Software Custodian is responsible to identify (in the Portable exhauster control system logbook.) that the CPU data files and the backup data files (on the engineering [SSTE] workstation[s]) are the same version. The Software Custodian is responsible to install the data files on all platforms. 
HNF-3097, Rev. 0

\subsubsection{PROTECTION FROM CATASTROPHE}

The software program and data files are protected from catastrophe by being located in CPU and at least one engineering (SSTE) workstation. These platforms are located in different buildings and should equipment (computer) failures occur, replacement hardware will be procured at that time.

\subsubsection{PROCUREMENT ITEMS}

Section 2.3.2 "Software Maintenance" identifies the procurement of a maintenance contract with the software vendor if required.

\subsection{DESIGN LIFE AND DECOMMISSIONING}

The life expectancy of the Portable exhauster is approximately ten years. The CPU is built for the current exhauster's. As upgrades occur on the SLC hardware the program may need to be changed and/or updated. The current SLC 500 is year 2000 (Y2K) compliant. The exception is the Wonderware. The 320 project is not utilizing the operator console there fore there is no $\mathrm{Y} 2 \mathrm{~K}$ issue. 